\title{
Research on the Influence of Firm's Innovation Driven on New Product Innovation Performance
}

\author{
Qu Yan ${ }^{1}$, Chun-Shuo Chen ${ }^{2}$ \\ ${ }^{1}$ Doctoral Candidate in Business Administration at the China-ASEAN International College, Dhurakij Pundit \\ University, Bangkok, Thailand; Shandong Yingcai University, China \\ ${ }^{2}$ MBA Program, China-ASEAN International College, Dhurakij Pundit University, Thailand \\ Correspondence: Qu Yan, China-ASEAN International College, Dhurakij Pundit University, Thailand.
}

Received: June 26, 2018

doi:10.5539/ibr.v11n8p110

\author{
Accepted: July 11, 2018 \\ Online Published: July 19, 2018 \\ URL: https://doi.org/10.5539/ibr.v11n8p110
}

\begin{abstract}
New product innovation and R\&D are important sources for firms to obtain competitive advantages, and market knowledge is the core element for firms to obtain new product innovation performance. However, it can be also found out that the relevant discussion upon innovation has been still limited to restricted theories and the developing empirical researching area by reviewing the literature. Based on knowledge-based theory, a questionnaire survey of 220 high-technology and internet firms in China was conducted to empirically analyze the relationship between innovation driven, potential absorptive capacity, and new product innovation performance. The study found that: the potential absorptive capacity mediates the relationship between market orientation and new product performance, technological opportunity and new product performance, and the potential absorptive capability positively adjusts the relationship between technological opportunities and realized absorptive capacity. It is possible to understand more clearly the process of firms acquiring and digesting information, transforming and mining knowledge to achieve new product innovation performance by analyzing the process of knowledge absorption and conversion.
\end{abstract}

Keywords: market orientation, technological opportunity, potential absorptive capacity, realized absorptive capacity, new product innovation performance

\section{Introduction}

In the era of knowledge economy, with the market competition becoming gradually more and more intense, firms that facing the dynamic, complicated and highly uncertain competition environment shall take the continuous innovation as the responding strategy for survival and development in order to maintain the advantageous competition capacity (Porter, 1980). Innovation is indeed the essential method for the development of a firm, an industry or even a country.

When it comes to the managers of an firm, however, it is just the task he is faced with and is to deal with that how to improve effectively the firm's performance, to give response to the target market more rapidly, to create new products or valuable services for customers, and to obtain the firm's advantage in competition (Ryzhkova \& PesÄMaa, 2015). With the development of Chinese economy, especially after entering WTO, the connection between domestic market and international market has been more and more enclosed. As a result, Chinese firms are facing both the new competition in domestic market and new challenge in globalized market. According to the authoritative data from National Development and Reform Commission of China, around 150,000 firms are born in China every year while annually about 100,000 come to death; almost $60 \%$ bankrupt within 5 years while $85 \%$ in 10 years; more impressively, private firms share a 2.4 -year-old life on average. It is just because of the rapid changing of the market and the progress in technology that the amount of competitors from different industries and different areas is becoming larger and larger. While with the shortening of the life cycle of products, firms must have the ability to respond more quickly to grasp the opportunity brought about by technological development, which is the necessity to ensure their survival in the highly competitive environment. The firm invested huge resources in the new products to gain competitive advantage; the new product becomes the core of competitive advantage. Developing new products with unique benefits is crucial for firms to increase profits (Langerak, Hultink, \& Robben, 2004; Li \& Calantone, 1998). 
It was claimed by Slater and Narver (1994) that innovation, which would mostly come from market orientation, was "ability of core value creation", and that market orientation meant to establish the competitive advantage through attaching importance to customers and creating the comparatively better customer value (Narver \& Slater, 1990). However, the process from information to the innovation performance cannot be accomplished directly; Information must be digested, absorbed and translated into useful knowledge. It can be especially seen in the firms under the higher market orientation and more technological opportunity, which shall cultivate their capacity of knowledge translation in their process of realizing the innovation. They shall transform the market information and technological information obtained into the valuable knowledge for the development of firms through filtering, absorption and digestion in order to make the correct decision and to reach the innovation performance and competitive advantage (Stefania \& Małgorzata, 2015; Zahra \& George, 2002). Thus, this research takes the market orientation and technological opportunity as the Innovation-driven factors (Dosi, 1988), and raises the point that knowledge translation capacity must be embodied in the firm as the mediating factor.

\section{Literature Review and Research Hypotheses}

Knowledge itself is a part of the firm's resources, and in management science, the concept of knowledge economy was raised by Drucker (1969) which emphasized that the world economy was gradually motivated by the production, separation and usage of knowledge, and knowledge, regarded by him, was the one and only source of firm's obtaining the competitive advantage (Drucker, 2014).

It is pointed out by Knowledge-based view that knowledge is the most important resource and is of the highest strategic significance, and it is revealed that the fundamental cause of diversity of performance among firms is the diversity of knowledge base (Grant, 1996).

Different types and quantities of knowledge possessed by each firm are different, and there is a significant difference in the knowledge base formed thereby, which brings about the uniqueness of the firm, the difference in performance between firms, and the possibility of the firm's continued success. Extant research considers market knowledge is the main driver of product innovation performance (Atuahene-Gima, 1995; Atuahene-Gima et al., 2005). Firms can use and integrate knowledge resources to promote the performance of firm product innovation (Li \& Tsai, 2011).

This study takes the knowledge as the one and only source for firm to obtain the competitive advantage (Drucker, 2014), and takes the innovation-driven factors as the source of knowledge. In the research field of Resource-based theory, the rich research results in the Knowledge-based theory will provide a strong theoretical basis for this study.

\subsection{Market Orientation, Realized Absorptive Capacity and New Product Innovation Performance}

The main difference between a firm and its competitors comes from knowledge resources (Grant, 1996). Knowledge resource refers to the internal ability of the firm to be creative, unique, difficult to imitate, and the market knowledge is the most important above all (Luca \& Atuahene-Gima, 2007). Market knowledge refers to the knowledge of the customer and competitor that the firm has ( Day, 1994; Kohli \& Jaworski, 1990; Narver \& Slater, 1990). Market orientation plays an important role in a firm's ability to generate, disseminate and use better information about its customers and competitors (Kohli \& Jaworski, 1990). Firms of high market orientation will take the initiative to meet changing customer preferences, understand customer needs, and find the shortage of firm's ability or the emerging market opportunity, so as to develop the necessary ability. By analyzing the environment, it can create value for customers, and through the development of new products or services, it can promote its performance (Mohr, Sengupta, \& Slater, 2010). In this study, it is held that the more market information the organization has, the more it can promote the organization in cultivation of absorptive capacity and improve the competitive advantage of the firm.

First of all, according to the Knowledge-based theory, Grant (1996) proposed that knowledge is very important, but knowledge is not important in knowledge itself, but the mechanism of knowledge integration, indicating that knowledge integration is the source of competitive advantage. Therefore, knowledge itself is not too important, while the source of firm innovation performance is to acquire, assimilate, transform and exploit the knowledge through absorptive capacity. When an firm comes into contact with knowledge, it will influence the decision making of the firm (March \& Simon, 1993) and the development of the future ability (McGrath \& MacMillan, 1995). To the firm, market knowledge is the firm's first contact, and it can understand the current market situation, such as customers, suppliers, competitors and government departments. The diversity, width and depth of the knowledge will affect the firm knowledge acquisition. The more market information a firm has, the more it will increase the willingness of the organization to assimilate the information. Because the more market 
information means the more the firm can grasp about customer needs and competitors behavior; therefore, in order to seize the opportunity, firms will increase the tendency to digest the information, trying to put these information combined with the firm's strengths and weaknesses, to produce a unique knowledge (Mcdonald \& Madhavaram, 2007). That is to say, the more market knowledge the firm has, the more it tends to assimilate the related information, the more it would need to develop the ability of knowledge acquisition, absorption, digestion and application of new knowledge, namely the absorptive capacity, and absorptive capacity is necessary for the firm to improve long-term performance (Day, 1994).

Finally, the absorptive capacity of the firm is always interacting between new knowledge and the existing knowledge in order to realize the development and promotion of product. The effective acquisition and use of external knowledge affect the formation and accumulation of absorptive capacity (Kotabe et al., 2011). The organization's absorptive capacity of external knowledge is an important factor in determining innovation performance (Cohen \& Levinthal, 1990). The higher the absorptive capacity of the department or organization is, the stronger the ability is to master the information and environment of the firm, the better the ability is to identify the useful knowledge and apply it to the innovation, and the higher the performance of organizational innovation will be (Szulanski, 1996). The higher the absorptive capacity of the firm is, the better the ability is to master the information and the external environment, the better the ability is to identify the useful knowledge, and to absorb to create the valuable firm performance (Ahimbisibwe et al., 2016; Stefania \& Małgorzata, 2015). Based on the above discussion, the first hypothesis of this study as follows.

H1: Realized absorptive capacity mediates the relationship between market orientation and new product innovation performance.

\subsection{Technological opportunity, Realized Absorptive Capacity and New Product Innovation Performance}

A firm who is eager to has competitive advantage in the industry not only needs to have and control the rare and valuable resources, but also needs the integration mechanism within the firm to conduct the knowledge assimilation, transformation and application in order to provide new products and services for the customer, and then to gain a competitive advantage (Barney, 1991; Grant, 1996; Teece, 2007). In addition to market information, technological opportunity is another important factor in this study.

The firm shall has the ability to perceive the technology development and respond accordingly, which can improve the competitive advantage of firm (Srinivasan, Lilien, \& Rangaswamy, 2002). With more technology choices, firms have more opportunity to obtain competitive advantage through technological innovation. More technological opportunity means more external information and obtainable external technological knowledge, and the emergence of new technologies opens the door for product innovation; at the same time, these large technological information will become the motivation to promote the firm absorptive capacity (Lichtenthaler, 2016). The learning environment being more challenging can increase $R$ \& $D$ investment to cultivate the absorptive capacity of the firm. In the environment of low technological opportunity, with the lack of diversity for firm to seek knowledge, and the knowledge obtained is limited, optional possibility for team members will be greatly reduced, the willingness of employees to engage in the information conversion and exploration, in comparison with high technological opportunity, will be relatively low. In this case, the team members may rely on the familiar knowledge and the old, existing method to develop new products. As a result, the members will not have much desire to absorb external technological information.

Firms realize that they need to grasp the existing knowledge and technology to develop new products and create benefits to gain a competitive advantage (Bavarsad, Kayedian, Mansouri, \& Yavari, 2014). The specific technological environment provide team members with unexplored areas, and the possibility of the new development and utilization of knowledge, which produces a breakthrough innovation (Ahuja \& Lampert, 2001), resulting in innovation performance. The stronger absorptive capacity of firm has, the more technological information it can collect. Dissemination of information and response to market demand are conducted, and the new product development performance gets higher. Thus, the whole firm innovation performance gets also higher (Lichtenthaler, 2009). Therefore, this study proposes the second hypothesis as follows.

H2: Realized absorptive capacity mediates the relationship between technological opportunity and new product innovation performance.

\subsection{The Moderating Effect of Potential Absorptive Capacity on the Relationship between Market Orientation and Realized Absorptive Capacity}

Potential absorptive capacity refers to the ability of a firm to discover, acquire, and absorb knowledge. The stronger the potential absorptive capacity, the more firms are willing to absorb external knowledge. Under the 
circumstances the information about the market and competitors is constantly changing, the more market-oriented firms have, the more they can grasp potential needs of customers now and in the future. It also prompts firms to increase their tendency to digest market information, conduct information screening and transformation, convert customer and competitor information into valuable knowledge and cooperate with the firm's own advantages to improve new product innovation performance. The combination of high market connection capacity and high potential absorptive capacity can enhance the digestion of knowledge by firms and translate them into the ability of the firm to improve the performance of the firm. On the contrary, if the potential absorptive capacity is low, it means that the firm's ability to accept external knowledge within a certain period of time is not strong. At this time, although the firm has market orientation, the team members will not take the initiative to acquire knowledge and will reduce the number of members. The motivation for digesting this information, or even acquiring knowledge, cannot absorb and transform this market information into more useful knowledge. Therefore, this study proposes hypothesis 3.

H3: Potential absorptive capacity plays a positive regulatory effect on the relationship between market orientation and potential absorptive capacity.

\subsection{The Moderating Effect of Potential Absorptive Capacity on the Relationship between Technological Opportunity and Realized Absorptive Capacity}

The potential absorptive capacity reflects the ability of a firm to acquire and absorb external information and reflects the sensitivity of the organization to knowledge. Technological opportunity are the number managers perceive outside related technical knowledge and can continue to increase opportunity for R\&D investment related to this technology. The firm's investment in $R \& D$ not only generates new knowledge, but also helps to increase absorptive capacity, thereby creating innovation and gaining competitive advantage.

The stronger the firm's potential absorptive capacity, it will actively perceive the changes in the external market, especially the changes in technological opportunity. The more the firm can understand the current or future needs and actions of competitors or customers, the more the firm can make predictions on the development trend of the industry, grasp opportunity and encourage firms to filter and digest technology-related information, thereby transforming it into useful knowledge and fostering the firm's technological superiority. Technical knowledge refers not only to knowledge related to technological progress, but also to competitors' information (Tödtling, Lehner, \& Kaufmann, 2009); and the lower the firm's potential absorptive capacity, the organization will not actively seek changes in the external environment, the response of the demand is not obvious. At this time, even if the firm has technical opportunity, there is no potential need for the firm to pull; firms do not have more motivation to digest this information and are less motivated to digest and convert knowledge. As a result, there is less opportunity for new product innovation.

In summary, the stronger potential absorptive ability of firms will encourage firms to obtain better technical information, learn more technologies or gain more opportunity. The team members will be more likely to pay attention to the current technological opportunity, and the more technical selectivity, more likely the team members are to absorb foreign technical knowledge. On the other hand, in order to meet the rapid changes in technology, to win in the competition, firms will increase R \& D investment, enhance their own realized absorption capacity, and convert useful knowledge into new products. However, in the environment where the potential absorptive ability of the firm is low, the firms are unresponsive to the external. Even if the firm has the technological opportunity, the motivation of the firm to improve the realized absorptive capacity is not strong enough to convert the market knowledge into new products. Based on the above discussion, this study proposes hypothesis 4.

H4: Potential absorptive capacity plays a positive regulatory effect on the relationship between technological opportunity and absorptive capacity. The research framework is shown in Figure 1. 


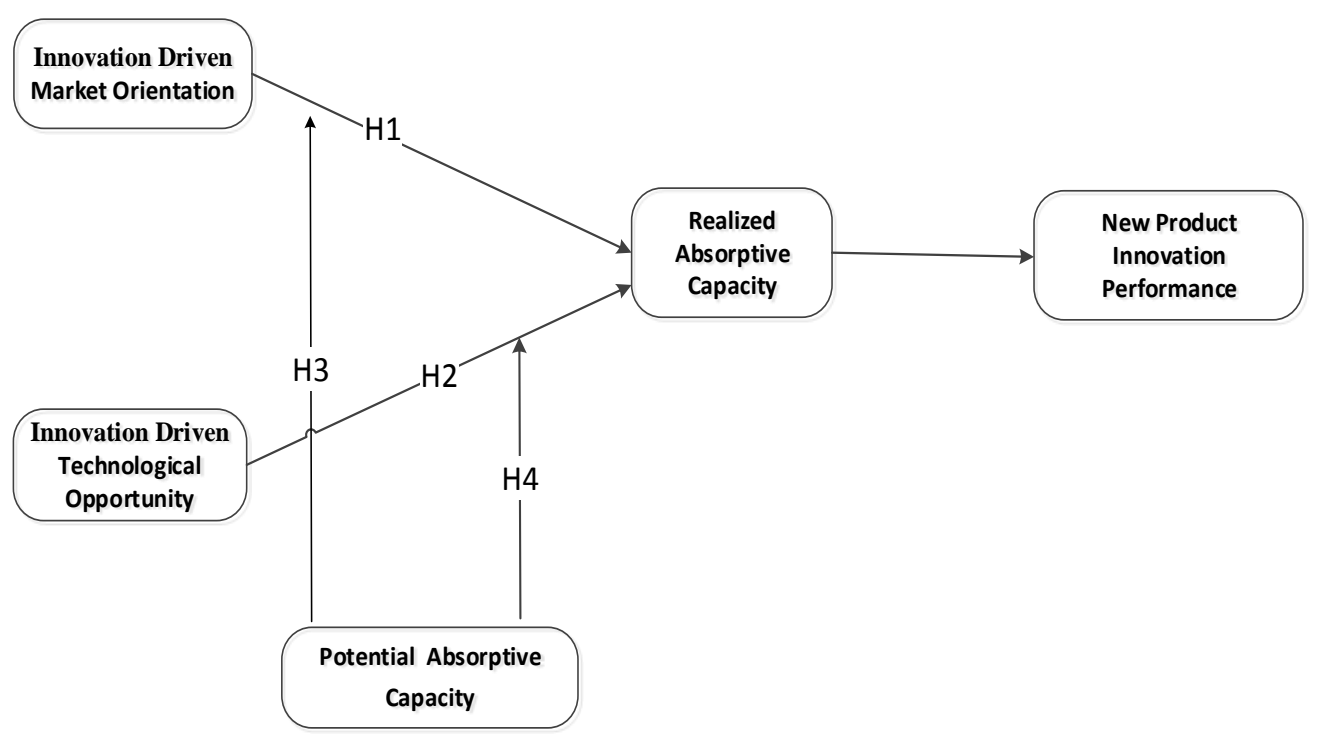

Figure 1. Research Framework

\section{Method}

\subsection{Samples and Data Collection}

This dissertation focuses on the relationship between innovation-driven, realized absorptive capacity and new product innovation performance in new product innovation. We followed the suggestions from earlier studies conducted in new product innovation (Atuahene-Gima \& Wei, 2011; Luca \& Atuahene-Gima, 2007; Catherine L. Wang \& Rafiq, 2014). Firstly, this study will focus on the high-technology industry, because the rewards of new products appear more spectacular in the hi-tech sector (Song \& Parry, 1997). Secondly, this study will focus on Internet firms. In recent years, the scale of China's Internet transactions has maintained a rapid growth rate.

In this paper, high-tech firms and Internet firms in Beijing and Shandong Province as research object, from March 2017 to May 2017, a total of 300 questionnaires were distributed, 230 questionnaires were returned, and a total of 220 valid questionnaires were obtained after removing invalid questionnaire. The recovery rate and the valid recovery rate of questionnaires were $77 \%$ and $73 \%$. The basic characteristics of the sample are shown in Table 1.

Table 1. Sample Characteristics

\begin{tabular}{llllll}
\hline \multirow{4}{*}{ Scale } & Below 100 persons & $26 \%$ & & Founding period & $13 \%$ \\
& $100-500$ & $43 \%$ & Growth period & $59 \%$ \\
& $500-1000$ & $26 \%$ & Stage & Mature period & $24 \%$ \\
& Above 1000 & $5 \%$ & & Recession & $4 \%$ \\
\hline \multirow{3}{*}{ Time } & Below 1 year & $5 \%$ & & High-Tech Firms & $63 \%$ \\
& $1-5$ year & $21 \%$ & \multirow{2}{*}{ Business } & Electric business firms & $23 \%$ \\
& $5-10$ year & $42 \%$ & manufacturing & $7 \%$ \\
& Above 10 year & $32 \%$ & & Wholesale and retail & $7 \%$ \\
\hline
\end{tabular}

\subsection{Variable Measurement and Verification}

Reliability and Validity analysis is used to test the questionnaire scale whether it has the stability and consistency in the measurement of latent variables. This study mainly used the Cronbach's $\alpha$ test; the greater the value is, the internal consistency of the questionnaire items is higher, and the Cronbach's $\alpha$ value should be higher than 0.70 (Nunnally \& Bernstein, 1994).

Validity analysis is used to measure scale questions, including content validity and construct validity. The questionnaires in this study mainly come from the widely cited mature scale, which is revised according to the opinions of experts and scholars; therefore, the questionnaire designed in this article has a high content validity. 
Confirmatory factor analysis was used to test the convergent validity and discriminate validity of the scale.

\subsubsection{Reliability Test}

The Cronbach's $\alpha$ coefficient; AVE, CR, and Factor Loading of each construct were calculated by software. Cronbach's $\alpha$ of five variables is between .837 and .931 , indicating that the scale has good internal consistency. The $\mathrm{CR}$ value of each construct is similar to $\alpha$, and $\mathrm{CR}>0.7$, so the questionnaire has good internal consistency and satisfies reliability requirements. $\chi^{2} / \mathrm{DF}$ is less than 5, NFI, NNFI, CFI, IFI, and RFI all meet the requirement of greater than 0.9, RMR satisfies the requirement of less than 0.1, and SRMR satisfies the requirement of less than 0.08 , so the questionnaire satisfies the validity requirement.

\subsubsection{Validity Test}

The validity and the discriminant validity were verified by Amos and summarized in Table 2 .

Table 2. Summary table of correlation coefficients

\begin{tabular}{lcccccccc}
\hline & MO & TO & PACAP & RACAP & NPIP & TIME & STAGE & SCALE \\
\hline 1 & 0.55 & & & & & & & \\
2 & 0.67 & 0.66 & & & & & & \\
3 & $0.61^{* *}$ & $0.57^{* *}$ & 0.65 & & & & & \\
4 & $0.73^{* *}$ & $0.53^{* *}$ & $0.52^{* *}$ & 0.58 & & & & \\
5 & $0.59^{* *}$ & $0.53^{* *}$ & $0.57^{* *}$ & $0.43^{* * *}$ & .54 & & & \\
Mean & 4.06 & 3.80 & 3.90 & 4.04 & 3.99 & 3.94 & 4.51 & 3.09 \\
SD & 0.51 & 0.54 & 0.56 & 0.55 & 0.68 & 0.44 & 15.1 & 1.47 \\
\hline
\end{tabular}

Note. $\mathrm{N}=220 ; * p<.05 ; * * p<.01 ; * * * p<.001$.

MO: Market Orientation PACAP: Potential absorptive capacity RACAP: Realized Absorptive Capacity NPIP: New Product Innovation Performance TO: Technological Opportunity

\section{Results}

The paper adopts Hierarchical Multiple Regression analysis to analyze the mediating role of realized absorptive capacity and the moderating role of potential absorptive capacity by using spss 19 and Amos 21 .

4.1 The Mediating Role of Realized Absorptive Capacity played between Market Orientation and New Product Innovation Performance

When analyzing the mediation effects of potential absorptive capacity on market orientation and new product innovation performance, three-step regression process will be used to test the mediation role of realized absorptive capacity (Baron \& Kenny, 1986). Meanwhile, three regression models will be established. In model 1, the independent variables are 3 control variables; firm establish time, firm scale and firm stage as well as market orientation, while the dependent variable is new product innovation performance. This model aims at studying the effects of these control variables and market orientation on new product innovation performance. In model 2, the independent variables are 3 control variables, firm establish time, firm scale and firm stage, as well as market orientation, while the dependent variable is realized absorptive capacity. This model aims at studying the effects of these control variables and market orientation on the realized absorptive capacity. In model 3 , realized absorptive capacity is added based on model 1 . In other words, model 3 is a full model containing all the control variables, market orientation, and realized absorptive capacity. Table 3 shows the regression operating results about mediation effects of realized absorptive capacity on market orientation and new product innovation performance. 
Table 3. Results for Mediated Regression Analysis

\begin{tabular}{|c|c|c|c|c|c|c|}
\hline \multirow{3}{*}{ Variables } & \multirow{2}{*}{\multicolumn{2}{|c|}{$\begin{array}{l}\text { Criterion } \\
\text { RACAP } \\
\text { Model } 2\end{array}$}} & \multirow{2}{*}{\multicolumn{4}{|c|}{$\begin{array}{c}\text { Criterion } \\
\text { New Product Innovation Performance }\end{array}$}} \\
\hline & & & & & & \\
\hline & B & $\mathrm{t}$ value & B & $\mathrm{t}$ value & B & t value \\
\hline TIME & .007 & .13 & .06 & .735 & .05 & .80 \\
\hline STAGE & -.05 & -.78 & -.15 & -1.75 & -.12 & -1.58 \\
\hline SCALE & -.002 & -.135 & .04 & 1.40 & .04 & 1.76 \\
\hline MO & .78 & $11.34^{* * *}$ & .79 & $8.11^{* * * *}$ & .18 & 1.52 \\
\hline RACAP & & & & & .78 & $7.06^{* * * *}$ \\
\hline F value & $32.38^{* * * *}$ & & $17.59^{* * *}$ & & $30.02^{* * *}$ & \\
\hline $\mathrm{R}^{2}$ & 0.51 & & .38 & & .55 & \\
\hline$\Delta \mathrm{R}^{2}$ & & & & & 0.17 & \\
\hline F change & & & & & $49.82^{* * *}$ & \\
\hline
\end{tabular}

p $<0.05 \quad{ }^{* *} \mathrm{p}<0.01 \quad{ }^{* * *} \mathrm{p}<0.001$

Note. This study used a two-tailed test for control variables and a one-tailed test for all hypotheses.

In Model 1, we use regression analysis to test the direct influence of market orientation on new product innovation performance. The results show that market orientation has a significant positive impact on new product innovation performance $(\beta=0.79, \mathrm{p}<0.001)$. In addition, Model 2 suggests that market orientation has a positive effect on potential absorptive capacity $(B=0.78, p<0.001)$. Finally, when realized absorptive capacity was added to Model 3 , it showed a positive and significant effect on new product innovation performance $(\beta=$ $0.78, \mathrm{p}<0.001)$.

From the analysis results, with the addition of realized absorptive capacity, the influence of market-oriented ability on new product innovation performance is reduced (from 0.79 to 0.18 ), but not significant, indicating that it is a complete intermediary, which explains the influence of market orientation on new product innovation performance is through realized absorptive capacity, we can transform the collected market information into knowledge and apply it to the development of new products to improve the performance of new product innovation. We further conducted a validation test based on the Sobel mediation process and found that market orientation has a positive effect on new product innovation performance through realized absorptive capacity. The direct impact is $0.61(0.78 * 0.78, \mathrm{t}=6.08, \mathrm{p}<0.01)$ (Hayes, 2013; Sobel, 1982). Therefore, Hypothesis H1 is supported.

\subsection{The Mediating Role of Realized Absorptive Capacity played between Technological Opportunity and New Product Innovation Performance}

When analyzing the mediation effects of realized absorptive capacity on technological opportunity and new product innovation performance, three-step regression process will be used to test the mediation role of realized absorptive capacity (Baron \& Kenny, 1986). Meanwhile, three regression models will be established. In model 1, the independent variables are 3 control variables; firm establish time, firm scale and firm stage, as well as technological opportunity, while the dependent variable is new product innovation performance. This model aims at studying the effects of these control variables and technological opportunity on new product innovation performance. In model 2, the independent variables are 3 control variables, firm establish time, firm scale and firm stage, as well as technological opportunity, while the dependent variable is realized absorptive capacity. This model aims at studying the effects of these control variables and technological opportunity on realized absorptive capacity. In model 3, absorptive capacity is added based on model 1. In other words, model 3 is a full model containing all the control variables, technological opportunity, and realized absorptive capacity. Table 4 shows the regression operating results about mediation effects of realized absorptive capacity on technological opportunity and new product innovation performance. 
Table 4. Results for Mediated Regression Analysis

\begin{tabular}{|c|c|c|c|c|c|c|}
\hline \multirow{3}{*}{ Variables } & \multirow{2}{*}{\multicolumn{2}{|c|}{$\begin{array}{l}\text { Criterion } \\
\text { RACAP } \\
\text { Model } 2 \\
\end{array}$}} & \multicolumn{4}{|c|}{$\begin{array}{c}\text { Criterion } \\
\text { New Product Innovation Performance }\end{array}$} \\
\hline & & & \multicolumn{2}{|r|}{ Model 1} & \multicolumn{2}{|c|}{ Model 3} \\
\hline & B & $\mathrm{t}$ value & B & t value & B & $\mathrm{t}$ value \\
\hline TIME & -.05 & -.84 & -.02 & -.27 & .02 & .31 \\
\hline STAGE & .04 & .48 & -.04 & -.49 & -.07 & -.99 \\
\hline SCALE & -.03 & -1.13 & .004 & .15 & .02 & 1.05 \\
\hline TO & .42 & $6.92^{* * * *}$ & .58 & $8.38^{* * * *}$ & .29 & $4.38^{* * * *}$ \\
\hline RACAP & & & & & .71 & $8.31^{* * * *}$ \\
\hline F value & $12.12^{* * *}$ & & $18.74^{* * * *}$ & & $37.67^{* * * *}$ & \\
\hline $\mathrm{R}^{2}$ & .27 & & .38 & & .61 & \\
\hline$\Delta \mathrm{R}^{2}$ & & & & & 0.22 & \\
\hline $\mathrm{F}$ change & & & & & $69.04^{* * * *}$ & \\
\hline
\end{tabular}

Note. This study used a two-tailed test for control variables and a one-tailed test for all hypotheses.

In Model 1, we use regression analysis to test the direct impact of technological opportunity on new product innovation performance. The results show that the technological opportunity has a significant positive impact on new product innovation performance $(B=0.58, \mathrm{p}<0.001)$. In addition, Model 2 suggests that technological opportunity has a positive effect on realized absorptive capacity $(B=0.37, p<0.001)$. Finally, when absorptive capacity was added to Model 3, it showed a positive and significant effect on the innovation performance of new products $(\beta=0.68, \mathrm{p}<0.001)$.

It can also be seen from the analysis results that with the addition of realized absorptive capacity, the influence of technological opportunity on new product innovation performance is reduced (from 0.58 to 0.29 ). However, it is still significant, indicating that it is a partial intermediary, which shows that the influence of technological opportunity on the new products innovation performance has two effects. One is the direct relationship between the two, and the other is the influence of technological opportunity on new product innovation performance is partly through realized absorptive capacity, which help the firm collect technological information and transformed them into knowledge, apply to new product development, and thus improve the performance of new product innovation. We further conducted a confirmatory test based on the Sobel mediation process and found that technological opportunity has a positive effect on new product innovation performance through absorptive capacity. The indirect effect is $0.30(0.42 * 0.71, \mathrm{t}=4.35, \mathrm{p}<0.01)$ (Hayes, 2013; Sobel, 1982). Therefore, hypothesis $\mathrm{H} 2$ is supported.

\subsection{Moderation Effects of Potential Absorptive Capacity on the Market Orientation and Absorptive Capacity}

A series of models established in this study based on the assumption of regulatory variables include: Model 1 consists of three control variables: firm establish time, firm scale and firm stage. Model 2 add market orientation and potential absorptive capacity based on model 1 . Model 3 composed of elements in model 2, as well as the product item of market orientation and absorptive capacity. Table 5 shows the regression results of potential absorptive capacity as a moderator.

Table 5. Results for Hierarchical Moderated Regression Analysis

\begin{tabular}{|c|c|c|c|c|c|c|c|}
\hline \multirow{2}{*}{ Variables } & \multicolumn{2}{|c|}{ Model 1} & \multicolumn{2}{|c|}{ Model 2} & \multicolumn{2}{|c|}{ Model 3} & \multirow[t]{2}{*}{ VIF } \\
\hline & $\beta$ & $\mathrm{t}$ value & $\beta$ & $t$ value & $\beta$ & t value & \\
\hline TIME & -.02 & -.26 & .02 & .39 & .02 & .44 & 1.593 \\
\hline STAGE & -.03 & -.33 & -.003 & -.07 & -.01 & -.18 & 1.483 \\
\hline SCALE & -.001 & -.04 & -.02 & -.94 & -.05 & -.88 & 1.161 \\
\hline MO & & & .48 & $6.45^{* * * *}$ & .48 & 6.45 & 1.610 \\
\hline PACAP & & & .44 & $6.42^{* * * *}$ & .46 & 6.29 & 1.870 \\
\hline MO_X_PACAP & & & & & .05 & .79 & 1.267 \\
\hline F value & 0.14 & & $43.18^{* * *}$ & & 35.97 & & \\
\hline $\mathrm{R}^{2}$ & -.022 & & .65 & & .65 & & \\
\hline$\Delta \mathrm{R}$ & & & 0.66 & & -0.001 & & \\
\hline F change & & & $41.17^{* * *}$ & & .63 & & \\
\hline
\end{tabular}

$* \mathrm{p}<0.05, \quad * * \mathrm{p}<0.01, \quad * * * \mathrm{p}<0.001$

Note. This study used a two-tailed test for control variables and a one-tailed test for all hypotheses.

In Table 5, all the coefficients of the variance inflation factor (VIF) are estimated to be lower than 10 (Mason \& Perreault Jr., 1991), which indicating that de-centralizing of the variables has no effect on the operating results. 
Model 1 shows that when explaining realized absorptive capacity, the control variable can explain $-2.2 \%$ for the variance. Model 2 shows that $\mathrm{R}^{2}$ increased by $66.1 \%(\Delta \mathrm{F}=41.166, \mathrm{p}<0.001)$ after adding independent variables (market orientation) and moderation variables (potential absorptive capacity). As we mentioned above, market orientation has a significant and positive effect on Absorptive Capacity $(\beta=0.44, p<0.001)$.

Model 2 also shows that potential absorptive capacity has significant and positive effect on absorptive capacity ( $\beta=0.48, p<0.001$ ), which means that the stronger the potential absorptive capacity outside, the more conducive for the firm to increase their potential absorptive capacity.

In Model 3, we added the regression equation of market orientation and potential absorptive capacity interaction terms to adjust the effects of market orientation on realized absorptive capacity, $\mathrm{R}^{2}$ decreased by $0.1 \%(\Delta \mathrm{F}=$ $0.63, \mathrm{p}>0.05$ ). This result shows that the influence of market orientation on realized absorptive capacity is not affected by the potential absorptive capacity. Hypothesis $\mathrm{H} 3$ is not supported.

\subsection{Moderation Effects of Potential Absorptive Capacity on the Technological Opportunity and Realized Absorptive Capacity}

In this work, a series of models are established based on the hypothesis of moderate variables: Model 1 is composed of 3 control variables: firm establish time, firm scale and firm stage; model 2 added independent variables technological opportunity and the regulatory variables potential absorptive Capacity; Model 3 composed of elements in model 2 , as well as the product item of technological opportunity and potential absorptive capacity. Table 6 shows the regression results of potential absorptive capacity as a moderation variable.

Table 6. Results for Hierarchical Moderated Regression Analysis

\begin{tabular}{|c|c|c|c|c|c|c|c|}
\hline \multirow{2}{*}{ Variables } & \multicolumn{2}{|c|}{ Model 1} & \multicolumn{2}{|c|}{ Model 2} & \multicolumn{2}{|c|}{ Model 3} & \multirow[t]{2}{*}{ VIF } \\
\hline & B & t value & $\beta$ & t value & B & $t$ value & \\
\hline TIME & -.02 & -.26 & -.003 & -.06 & .007 & .14 & 1.63 \\
\hline STAGE & -.03 & -.33 & .05 & .74 & .05 & .88 & 1.46 \\
\hline SCALE & -.001 & -.04 & -.03 & -1.50 & -.03 & -1.72 & 1.18 \\
\hline TO & & & .15 & $2.45^{* * *}$ & .14 & 2.31 & 1.57 \\
\hline PACAP & & & .61 & $8.06^{\text {***** }}$ & .57 & $7.56^{* * * * *}$ & 1.60 \\
\hline TO_X_PACAP & & & & & -.12 & $-2.06^{*}$ & 1.16 \\
\hline F value & .140 & & $28.08^{* * *}$ & & $24.77^{\text {*** }}$ & & \\
\hline $\mathrm{R}^{2}$ & -.022 & & .532 & & .55 & & \\
\hline$\Delta \mathrm{R}$ & & & 0.554 & & 0.04 & & \\
\hline F change & & & $64.96^{* * * *}$ & & 4.24 & & \\
\hline
\end{tabular}

Note. This study used a two-tailed test for control variables and a one-tailed test for all hypotheses.

In Table 6, all the coefficients of the variance inflation factor (VIF) are estimated to be lower than 10 (Mason \& Perreault, 1991), which indicating that de-centralizing of the variables has no effect on the operating results. Model 1 shows that when explaining potential absorptive capacity, the control variable can explain $-2.2 \%$ for the variance. Model 2 shows that $\mathrm{R}^{2}$ increased by 55.4\% $(\Delta \mathrm{F}=64.69, \mathrm{p}<0.001)$ after adding independent variables (technological opportunity) and moderation variables (potential absorptive capacity). As we mentioned above, technological opportunity has a significant and positive effect on potential absorptive capacity $(B=0.15, \mathrm{p}$ $<0.001)$.

Model 2 also shows that potential absorptive capacity has significant and positive effect on realized absorptive capacity $(\beta=0.11, \mathrm{p}<0.01$ ), which means that firm's increased strength and emphasis on potential absorptive capacity will help improve the firm's potential absorptive capacity..

In Model 3, we added the regression equation of technological opportunity and realized absorptive capacity interaction terms to adjust the effects of technological opportunity on realized absorptive capacity, $\mathrm{R}^{2}$ increased by $1.3 \%(\Delta \mathrm{F}=4.239 \mathrm{p}<0.05)$. One-tailed tests are often used to verify the hypothesis of the direction of the forecast, the effect of technological opportunity and potential absorptive capacity on the realized absorptive capacity is significant $(B=-0.12, \mathrm{t}=-2.06, \mathrm{p}<0.05)$. With stronger potential absorptive capacity, there is a negative relationship between technological opportunity and potential absorptive $(\beta=0.07, \mathrm{t}=0.99, \mathrm{p}$ $<0.01)$. When potential absorptive capacity is lower, there is a positive relationship between technological opportunity and potential absorptive capacity $(\beta=0.21, \mathrm{t}=3, \mathrm{p}<0.01)$.

This result shows that potential absorptive capacity has a significant effect on technological opportunity and realized absorptive capacity relative lower potential absorptive capacity. Therefore, hypothesis H4 is supported. 


\section{Discussion and Conclusions}

In extant research, there is a relative lack on the formation of absorptive capacity and internal change mechanisms, and there are still differences in the function path of absorptive capacity on new product innovation performance. This dissertation, taking the framework of Zahra and George (2002) as the theoretical basis, and the innovation-driven factors as the knowledge sources, has validated the view that knowledge is the main source for the firm to obtain the new product innovation performance in order to obtain the competitive advantage. Based on this, the empirical verification of the framework has been made. Simultaneously, it was pointed out by Dosi (1988) that the innovation of the firm comes from mainly the demand pull and technology push, while Day (1994) also raised that firms motivated by market could present the high market sensemaking capacity, which could become the guidance for it to obtain the ability of connection of internal and external areas, for instance the firm's absorptive capacity.

This study empirically explores the process of innovation-driven, realized absorptive capacity and new product innovation performance. In the process of transforming external knowledge into new product innovation performance, it is not enough to merely acquire and absorb external information. Only the information can be converted into useful knowledge that can be utilized by the team members or organizations, that is realized absorption capacity, which may be helpful for new product development. In the relationship between market orientation and potential absorptive capacity, the moderator of potential absorptive capacity has not played a corresponding role. With higher market orientation and the firm will has more market knowledge, the firm can directly apply the acquired market information. However, with the increase of technological opportunities, potential absorption capacity plays a negative regulatory role between technological opportunities and potential absorptive capacity.

Absorptive capacity can promote the new product development performance, which has been widely accepted by academic circles. This study supports this conclusion and provides some implications for managers in the following aspects.

Firstly, firm managers must pay attention to market knowledge, grasp the market conditions, pay attention to the changes of customers and competitors, and constantly obtain the information needed by enterprises in order to win in the market competition and obtain competitive advantages. Secondly, firm should cultivate the learning ability and enterprise's perception of external information and knowledge, so that enterprises can perceive and grasp the development pulse of new knowledge and new technologies, screen information, and absorb useful information, which in turn translates into useful knowledge; at the same time, only information can be absorbed, converted into useful knowledge and used by group members or individuals to promote product performance. Therefore, firms should create a relaxed, positive learning environment to promote the absorption and transformation of external knowledge for employees. For the acquired new technologies and knowledge, managers should organize experts to learn and digest new knowledge, organize internal learning, and translate into useful knowledge for the firm to improve new product innovation performance.

There are several limitations in the process of elaborating the results. First of all, the data are mainly from China, and the sample data are mainly from Beijing and Shandong Province. Therefore, the universality of the results is limited. Secondly, although some variables, such as firm time, firm stage and firm scale were controlled, they did not include some potential influence factors such as $R \& D$ input intensity that were widely considered in previous studies (Li \& Calantone, 1998). In the future research, these contents can be further studied. Lastly, sample data used in this study was cross-sectional data. Future research can target a certain amount of firm sample data and select longitudinal data with a certain time span to further discuss, and dynamically explain the evolution mechanism of potential absorptive capacity, realized absorptive capacity and its impact on new product innovation performance.

\section{References}

Ahimbisibwe, G. M., Nkurunziza, G., \& Nyamuyonjo, D. (2016). Knowledge absorptive capacity: do all its dimensions matter for export performance of SMEs? World Journal of Entrepreneurship, Management and Sustainable Development, 12(2), 139-160. https://doi.org/10.1108/WJEMSD-09-2015-0041

Ahuja, G., \& Lampert, C. M. (2001). Entrepreneurship in the large corporation: a longitudinal study of how establised firms create breakthrough inventions. Strategic Management Journal, 22(6/7), 521-543. https://doi.org/10.1002/smj.176

Atuahene-Gima, K. (1995). An exploratory analysis of the impact of market orientation on new product performance : a contingency approach. Journal of Product Innovation Management, 12(4), 275-293. 
https://doi.org/10.1016/0737-6782(95)00027-Q

Atuahene - Gima, K., Slater, S. F., \& Olson, E. M. (2005). The contingent value of responsive and proactive market orientation on new product program performance. Journal of Product Innovation Management, 22(6), 464-482. https://doi.org/10.1111/j.1540-5885.2005.00144.x

Bavarsad, B., Kayedian, A., Mansouri, Z., \& Yavari, F. (2014). Studying the effect of social capital and technological opportunities on innovation with the mediator role of knowledge absorptive capacity. International Journal of Operations \& Logistics Management, 3(4), 302-311.

Cohen, \& Levinthal. (1990). Absorptive capacity: A new perspective on learning and innovation. Administrative Science Quarterly, 35(1), 128-152. https://doi.org/10.2307/2393553

Day. (1994). The capabilities of market-driven organizations. Journal of Marketing, 58(4), 37-52. https://doi.org/10.2307/1251915

Dosi, G. (1988). Sources, procedures, and microeconomic effects of innovation. Journal of Economic Literature, 26(9), 1120-1171.

Drucker. (1969). The Age of Discontinuity; Guidelines to Our Changing Society. Population, 9, 413.

Drucker. (2014). Innovation and entrepreneurship. Routledge.

Grant, R. M. (1996). Toward a knowledge - based theory of the firm. Strategic Management Journal, 17, 109-122. https://doi.org/10.1002/smj.4250171110

Kohli, A. K., \& Jaworski, B. J. (1990). Market orientation: the construct, research propositions, and managerial Iimplications. Journal of Marketing, 54(2), 1-18. https://doi.org/10.2307/1251866

Kotabe, M., Jiang, C. X., \& Murray, J. Y. (2011). Managerial ties, knowledge acquisition, realized absorptive capacity and new product market performance of emerging multinational companies: A case of China. Journal of World Business, 46(2), 166-176. https://doi.org/10.1016/j.jwb.2010.05.005

Langerak, Hultink, \& Robben. (2004). The Impact of Market Orientation, Product Advantage, and Launch Proficiency on New Product Performance and Organizational Performance. Journal of Product Innovation Management, 21(2), 79-94. https://doi.org/10.1111/j.0737-6782.2004.00059.x

Li, \& Calantone. (1998). The Impact of Market Knowledge Competence on New Product Advantage: Conceptualization and Empirical Examination. Journal of Marketing, 62(4), 13-29. https://doi.org/10.2307/1252284

Li, \& Tsai. (2011). Knowledge Resource, Product Innovation Performance, And The Mediating Role Of Knowledge Utilization Capability. Proceedings for the Northeast Region Decision Sciences Institute.

Lichtenthaler, U. (2009). Absorptive capacity, environmental turbulence, and the complementarity of organizational learning processes. Academy of Management Journal, 52(4), 822-846. https://doi.org/10.5465/amj.2009.43670902

Lichtenthaler, U. (2016). Determinants of absorptive capacity: the value of technology and market orientation for external knowledge acquisition. Journal of Business \& Industrial Marketing, 31(5), 600-610. https://doi.org/10.1108/JBIM-04-2015-0076

Luca, L. M. D., \& Atuahene-Gima, K. (2007). Market knowledge dimensions and cross-functional collaboration: examining the different Routes to product innovation performance. Journal of Marketing, 71(1), 95-112. https://doi.org/10.1509/jmkg.71.1.95

March, J. G., \& Simon, H. A. (1993). Organizations Revisited. Industrial \& Corporate Change, 2(1), 299-316. https://doi.org/10.1093/icc/2.1.299

Mcdonald, R. E., \& Madhavaram, S. (2007). What firms learn depends on what firms know: The implications of prior knowledge for market orientation. Marketing Management Journal, 17(1), 171-183.

McGrath, R. G., \& MacMillan, I. C. (1995). Defining and developing competence: a strategic process paradigm. Strategic Management Journal, 16(4), 251-275. https://doi.org/10.1002/smj.4250160402

Mohr, J., Sengupta, S., \& Slater, S. (2010). Marketing of high technology products and innovations: 3rd edition.

Narver, J. C., \& Slater, S. F. (1990). The effect of a market orientation on business profitability. Journal of Marketing, 54(4), 20-35. https://doi.org/10.2307/1251757

Porter. (1980). Competitive strategy : techniques for analyzing industries and competitors : with a new introduct: Free Press. 
Ryzhkova, \& Pesämaa. (2015). Absorptive Capacity, Collaboration with Customers and Innovation Performance of Gazelle Companies in Knowledge-Intensive Industries. International Journal of Innovation Management, 19(05), 1-27. https://doi.org/10.1142/S1363919615500590

Slater, S. F., \& Narver, J. C. (1994). Does competitive environment moderate the market orientation-performance relationship? Journal of Marketing, 58(1), 46-56. https://doi.org/10.2307/1252250

Srinivasan, R., Lilien, G. L., \& Rangaswamy, A. (2002). Technological opportunism and radical technology adoption: an application to E-business. Journal of Marketing, 66(3), 47-60. https://doi.org/10.1509/jmkg.66.3.47.18508

Stefania, \& Małgorzata, L. (2015). Capturing absorptive capacity: concepts, determinants, measurement modes and role in open innovation. International Journal of Management \& Economics, 45(1), 115-120. https://doi.org/10.1515/ijme-2015-0015

Szulanski, G. (1996). Exploring internal stickiness: Impediments to the transfer of best practice within the firm. Strategic Management Journal, 17, 27-43. https://doi.org/10.1002/smj.4250171105

Teece. (2007). Explicating dynamic capabilities: the nature and microfoundations of (sustainable) enterprise performance. Strategic Management Journal, 28(13), 1319-1350. https://doi.org/10.1002/smj.640

Tödtling, F., Lehner, P., \& Kaufmann, A. (2009). Do different types of innovation rely on specific kinds of knowledge interactions? Technovation, 29(1), 59-71. https://doi.org/10.1016/j.technovation.2008.05.002

Zahra, S. A., \& George, G. (2002). Absorptive capacity: a review, reconceptualization and extension. Academy of Management Review, 27(2), 185-203. https://doi.org/10.5465/amr.2002.6587995

\section{Copyrights}

Copyright for this article is retained by the author(s), with first publication rights granted to the journal.

This is an open-access article distributed under the terms and conditions of the Creative Commons Attribution license (http://creativecommons.org/licenses/by/4.0/). 